DOI https://doi.org/10.36059/978-966-397-117-9/17-35

\title{
PROBLEMS OF DISTRIBUTION OF STATE AND LOCAL AUTHORITIES IN UKRAINE
}

\section{Bortnyak V. A.}

\section{INTRODUCTION}

The modern world is changing rapidly. Development of situation in Eastern Ukraine showed that the system of public administration Ukraine was unprepared to prevent and respond to acts of aggression of the Russian Federation, and therefore needs to be improved. The strategic planning system requires improvement. Strategic planning as a function of public administration defines goals, objectives, priorities and a set of measures to implementation of state policy. According to the National Security Strategy of Ukraine improving the state of strategic planning, a unified system of monitoring, analysis, forecasting and decision-making in national security and defence is one of the priorities of the national security policy.

Decentralization of power and an effective system of local government is the most important aspect of the modern state. At present proper local government is an important factor in the democratization of public life, decentralization and a prerequisite of civil society. As the example of the European Union's democratic and effective governance, Ukraine should build a viable democratic state, the legal framework which meets EU legal framework and the rule of law. For example, as the base of decentralization in France, Germany and Poland is territorial reform and decentralization, which are based on the principles of the Charter and the draft charter on regional self-government. Thus, the system of local government in Ukraine needs drastic changes, regulatory, at first, material and financial, logistical and information support. The aim of the study is to examine the current system of local government in Ukraine, scientific analysis of the feasibility and benefits of implemented reforms for decentralization and subsidiary of local authorities, decentralization of public power and public control, and the need to strengthen the political status of local governments. 


\section{Political struggle in Ukraine: the establishment of power}

On June 28 Ukraine marked the Constitution Day. Twenty two years ago, back in 1996, the Ukrainian state adopted its Supreme Law. Today it has again come into the spotlight before the presidential elections Yuliya Tymoshenko, whom the opinion polls dub the leader of the presidential campaign, claims the need for the "new social contract". Meanwhile, the actual President Poroshenko spoke of his intention to introduce into the Constitution Ukraine's aspiration to become an EU and NATO member. These attempts to change the Constitution are not new to Ukrainian politics: over the 22 years the Law has been subject to change six times, and it thus reflects well the country's past as well as all its political battles. UCMC takes a look at the path of Ukraine's Supreme Law, its most daunting problems and at the changes to expect shortly ${ }^{1}$.

MPs managed to adopt the Supreme Law in long-standing discussions during the presidency of Leonid Kuchma. It happened on the legendary "Constitutional night" of June 28, 1996. Since then Ukrainians got to live through many changes that the Constitution incurred. Nearly each president was trying to amend it to his benefit in the standoff with the Parliament, the most persistent in this regard turned to be Viktor Yanukovych. The Supreme Law has always been slightly inconvenient for the state leaders, and they were thus trying to rewrite it in this or that way in order to change the balance of powers in the country.

One of the biggest collisions of the Ukrainian Constitution is the balance of power between the President and the Parliament. It is this balance that has seen the biggest battles unfold around it over the past two decades. For ten years - between 1996 and 2006, Ukrainians lived in a parliamentary-presidential republic where the President enjoyed wide powers. Then between 2006 and 2010 - Ukraine turned into a presidential-parliamentary republic with the strong Parliament. Afterwards there was a switch back to the presidential model that lasted four years until 2014. Finally, after Euromaidan the Parliament regained more powers once again. The return to the parliamentary-presidential model occurred in February 2014 after the presidential powers of Viktor Yanukovych were suspended ${ }^{2}$.

Starting from 2003 political forces of Viktor Yanukovych and Leonid Kuchma initiated the constitutional reform that sought to weaken the

\footnotetext{
${ }^{1}$ Ситник Г. П. Державне управління у сфері націо- нальної безпеки (концептуальні та організаційноправові засади) : підручник. Г. П. Ситник. К. : НАДУ, 2017. С. 119.

${ }_{2}$ Ситник Г. П. Державне управління у сфері націо- нальної безпеки (концептуальні та організаційноправові засади) : підручник. Г. П. Ситник. К. : НАДУ, 2017. С. 204.
} 
President's powers and to pass to the Verkhovna Rada (Ukraine's Parliament) the right to form the government of Ukraine. Their motivation was quite simple: they realized they were not going to win the presidential elections. The "Orange" forces of the opposition of Yushchenko and Tymoshenko were ardently protesting against the reform as they were confident in the victory of their candidate at the presidential elections of $2004^{3}$.

The Law amending the Constitution (on the political reform) foresaw the transition from the presidential-parliamentary to the parliamentarypresidential governance form as well as empowered the coalition of parliamentary factions to form the government and extended the term in the office for MPs to five years. The changes came into force in 2006 after the victory of the Orange Revolution and boasted support from the thenPresident Yushchenko who then made a decision to unite with the political force of his former opponent Yanukovych joining forces against Yuliya Tymoshenko ${ }^{4}$.

It comes as a paradox but after Viktor Yanukovych and hisParty of Regions acceded to power the party's position as to the state system made a 180-degree turn. At the post of the President Yanukovych was in try to reinforce his power. On September 30, 2010 Ukraine's Constitutional Court, under the evident pressure by Yanukovych, ruled previous constitutional changes that he himself had initiated several years before being not in line with the Constitution of Ukraine. The Ukraine's Constitutional Court restored in power the Constitution of 1996 and Ukraine became a presidential-parliamentary republic again.

Last time the Constitution was subject to change following the Revolution of Dignity. On February 21, 2014 the then-president Viktor Yanukovych and the leaders of the opposition signed an agreement that foresaw the return to the Constitution of 2004 balancing the powers of the Cabinet of Ministers (the government), the President and the Parliament. The Verkhovna Rada voted in the draft on the same day. The President Poroshenko elected several months after, has not been changing the balance of power since then.

Throughout Poroshenko's presidency the balance of power has not been subject to change. Instead the President initiated and implemented several important changes to the Constitution.

\footnotetext{
3 Семенченко А. I. Методологія стратегічного планування у сфері державного управління забезпеченням національної безпеки України. А. І. Семенчен- ко. К. : НАДУ, 2015. С. 163.

4 Семенченко А. І. Методологія стратегічного планування у сфері державного управління забезпеченням національної безпеки України. А. І. Семенчен- ко. К. : НАДУ, 2015. С. 187.
} 
Several months after Petro Poroshenko was elected President, a draft law on decentralization introducing amendments to the Constitution was submitted to the Parliament.

The main novelties that the draft law brought were financial decentralization of the regions and posts of prefects, it also granted to the President the right to dismiss local councils and a possibility for specific local self-governance in the defined regions of Donetsk and Luhansk regions. The draft law in question passed the first reading only. On June 2, 2016 the Verkhovna Rada adopted the changes to the Constitution in the justice part to re-launch the judicial system and set the judiciary free from corruptionists. The main principles of the judicial reform became the return to the three-layer judicial system, establishing of the Supreme Council of Justice, mandatory re-attestation of all Ukraine's judges, mandatory asset declaration for judges and their family members as well as stripping them off the immunity.

In mid-June the Constitutional Court of Ukraine ruled constitutional the presidential draft law amending the Constitution's Article 80 (revoking the immunity of MPs) that is to revoke the parliamentary immunity starting from early 2020. The document is still a draft law and is subject to the parliamentary voting. On the Constitution Day the President insisted that European integration should be affirmed by the Supreme Law. Petro Poroshenko said he would soon submit a proposal to the Parliament to amend the Constitution respectively. The amendments are supposed to affirm Ukraine's aspirations to become a member of the EU and NATO 5 .

The numerous amendments made to the Supreme Law in course of all the political battles of the past decades are not the only problem of Ukraine's Constitution. Other drawbacks include imperfect text and, in particular, the contradictory definition of economic rights that may become an obstacle on the way to reforms. So that the voices of those aiming for the new Constitution will be becoming louder each time.

The Constitution contains a series of economic rights that the state cannot provide for. "This Constitution has served its term for a series of reasons. Firstly, it is unrealistic. When the Constitution is lying, so does everyone else. The Constitution contains a whole block of rights, the socalled economic rights that only the countries having the GDP per capita of USD 30 thousand per year may afford. (...) When they talk about

\footnotetext{
5 Богданович В. Ю. Основи державного управління забезпеченням обороноздатності України: теорія і практика. В. Ю. Богданович, М. Ф. Сжеєв, І. Ю. Свида. Львів : ЛІСВ, 2015. С. 119.
} 
affordable accommodation, free healthcare and education here, they are actually killing the healthcare, doctors, patients and higher education neither of our universities entered the world's top 100 ranking," lawyer and activist Hennadiy Druzenko said during the forum "The Country's New Plan" (Novyi kurs krayiny) organized by Yuliya Tymoshenko. The healthcare reform that kick-started this year has already come across the criticism: the aspirations of the healthcare reformers to clearly define free and paid services, introduce insurance-based healthcare system have already come across a populist argument that the Constitution stipulates the right to "free healthcare"

Moreover the Constitution is being often criticized for being eclectic - comprising the provisions from the Soviet Union times and the current European ones. From the very beginning it was a transitional document requiring change. One may clearly sense the conflict between the then-left forces (the Socialist Party) and the then-reformers (Leonid Kuchma's party) in the text of the Supreme Law. These contradictions do not come to a compromise, instead they lead to eclecticism and result in contradictory provisions.

The complexity of the situation lies in the fact that despite the imperfection of the actual text of the Constitution, it does not allow for adoption of a brand new Supreme Law. Even its biggest critics admit it. "Since the Constitution's adoption in 1996 it has been changed several times to an extent when it is not clear what is functioning in the state and in what way. So that the only way out of this situation is to adopt a new Supreme Law of Ukraine," the first president of Ukraine Leonid Kravchuk said. At the same time he claims that the actual Constitution contains an article prohibiting the adoption of a new Supreme Law. The article suggests that the document can only be amended not changed entirely.

Whether these will be amendments to the law or a new constitution the main problem stays in the attempts to politicize the Supreme Law as well as the respective crisis of trust to it in the wider society. If the Constitution stipulates what is not actually there in practice and what cannot ever happen, if every political force is rewriting the law to its benefit, it undermines the citizens' trust to the state. Restoring this trust would be the priority task for the Ukrainian political class.

\footnotetext{
6 Семенченко А. І. Методологія стратегічного планування у сфері державного управління забезпеченням національної безпеки України. А. І. Семенчен- ко. К. : НАДУ, 2015. С. 354.
} 


\section{The system of state administration against the actions of the Russian Federation}

The functions of strategic planning are prognostic, programming and design. Sometimes they are referred to the procedures of strategic planning. This strategic prognostication - a form of planned activities is to anticipate the scientific prediction of the object at a specified future time. Analysis conducted by the results of the results of the Defence Review within the framework of the comprehensive review of the Security and Defence Sector of Ukraine. Determined that the development of the politico-military environment throughout the world and around Ukraine is determined by the following major trends: the establishment of the multipolar relations system, attempts to change the existing power balance, first of all by the leading world nations ${ }^{7}$.

This is reflected in the fact that over the recent years the role of the world's major centres of power such as the North American led by the USA, the Western Europe under the leadership of the European Union, the Eurasian led by the Russian Federation, the Asia-Pacific with leading positions of China and Japan is being strengthened. There is also the establishment of new centres of power under the auspices of such countries as India, Turkey, Iran and Brazil. Under current conditions there are attempts to change the existing balance of powers among the major global centres; intensification of contradictions between the leading centres of power regarding the division of spheres of influence. Aggravation of geopolitical rivalry between the Euro-Atlantic and European collective security systems on the one hand, Eurasian and AsiaPacific systems - on the other remains crucial for the formation of politico-military situation at the current stage of global change.

The growth of economic, technical and military potentials of the global centres' participants leads to intensification of the struggle for influence in areas of their strategic interests. The growth of international competition for access to natural, technological and other resources significantly affects the formation of the politico-military situation in the world. Intensification of contradictions between the global centres of power results in the retention of «frozen» and the emergence of new conflicts, their periodic aggravation in the Caucasus and Central Asian regions, the Balkans, the Middle East, Ukraine, Transnistria and other regions. Support of separatism, ethnic and religious confrontation, internal

7 Сектор безпеки і оборони України : зб. наук. матеріалів / [Ф. В. Саганюк, М. М. Лобко, О. В. Устименко, В. І. Пеньковський] ; за ред. Р. І. Тимошенка. К. : Майстер книг, 2018. С. 85. 
instability, causing «loyal regimes» provides the basis for aggravation of contradictions and the emergence of new armed conflicts; the increase of interdependence of the leading states in the context of globalization, the growth of influence of leading global corporations, intensification of struggle for natural resources, use of energy factor for political ends. Globalisation is a characteristic feature of the current world evolution, which significantly influences the economies of states, strengthens their interdependence, and sharpens rivalry for access to energy resources ${ }^{8}$.

Along with the positive factors globalisation provokes the increase of inequality in the distribution of world resources, leads to turbulence of international capital flows and related conflicts and crises. The division of the world into rich centre and poor provinces still remains the problem in the context of development gaps of the countries belonging to the socalled «golden billion» and other countries. A negative consequence of globalisation is the political instability, which is manifested in the increasing number of disabled, unrecognised states and degrading or failed states. There is a crisis of power in many countries, the development of democratic processes is being constrained, separatist movements are gaining momentum.

The situation is deteriorating as a result of crisis processes in macroeconomics. Escalating competition is being expected, particularly in such areas as access to resources (primarily - energy), struggle for maintenance and expansion of zones of influence; the reduction of the efficiency of measures applied for crisis management and military conflicts settlement by the leading international organizations. Cooperation with the leading global and regional international organizations, maintenance of mutually beneficial partnership relations at the bilateral level remains an important factor in creating foreign policy conditions that will affect the security level of any country of the world. However, there is a tendency to reduce the effectiveness of mechanisms of countering aggression by the existing international collective security systems. Under these conditions, strong states are trying to impose their will on weaker partners contrary to international law9.

This explains the aspiration of many countries to provide their own security through active cooperation with EuroAtlantic and European collective security systems; preserving the role of military force as a

\footnotetext{
8 Сектор безпеки і оборони України : зб. наук. матеріалів / [Ф. В. Саганюк, М. М. Лобко, О. В. Устименко, В. І. Пеньковський] ; за ред. Р. І. Тимошенка. К. : Майстер книг, 2018. С. 119.

Yarger Harry R. (Harry Richard) Strategy and the national security professional : strategic thinking and strategy formulation in the 21 th century. Harry R. Yarger.
} 
means of solving problematic issues of politico-military relations. Over the recent years there has been a tendency towards more explicit use of military force in pursuance of politico-military objectives. At the same time there are significant changes in forms and ways of using military force, new approaches to armed struggle appear, including the use of nongovernmental paramilitary organizations. In many cases this reduces the effectiveness of international collective security systems and complicates the application of international law to resolve conflicts; the desire of individual states to succeed in the military-technical sphere and create opportunities for the production of weapons of mass destruction.

Despite the difficult financial and economic conditions of the global economy development after 2008-2009 crisis, there is an increase of military budget of the countries, purchase of new materiel, the increased danger of uncontrolled proliferation of nuclear weapons, carriers and materials for their production, as well as dual-use technologies; the spread of terrorism (including cyberterrorism), piracy, organized crime, illegal immigration, illicit trade in arms, drug and human trafficking. international terrorism, piracy, transnational organized crime, human, arms and drugs trafficking, «black transplantation», struggle for spheres of influence, violent shift of power in certain countries are leading to the increased international instability. There is a rapid intensification of terrorist activities in cyberspace ${ }^{10}$.

The solution of such problems requires consolidated efforts by the whole international community; acceleration of the information technologies development, increasing the capabilities of states to conduct information and information-psychological operations, increasing the sensitivity of the society to the death of peaceful population and casualties of military units in armed conflicts. The information factor within foreign policy implementation of the leading nations and insurance of their national interests accords even greater importance. This is increased by the swift development of the newest technologies.

As the recent years has shown, the value of information technology for the achievement of geopolitical goals will grow and acquire the role of one of the main factors in modern conflicts. Modernization and improvement of technical intelligence systems by the foreign intelligence services, increase of their capabilities, attempts of unauthorized access to the information infrastructure of the state and its use against the interests

\footnotetext{
${ }^{10}$ National Security Strategy and Strategic Defence and Security Review 2015 [Електронний ресурс]. Режим доступу : https://www.gov.uk/government/ uploads/system/uploads/attachment_data/ file/478933/52309_Cm_9161_NSS_SD_Review_web_only.pdf
} 
of Ukraine, monopolization of the telecommunications services market by the large foreign companies and their attempts to impose to the state their conditions for national information and communication networks and systems operation are becoming threatening factors for the information security system functioning in Ukraine, hinder the development and use of information sphere and endanger the vital interests of human and citizen as well as society and the state under the conditions of information society development and globalization of information exchange in Ukraine; global climate changes, depletion of natural resources, growing deficit of drinking-water, food and increased migration in the world.

Global climate changes along with other global humanitarian issues: aggravation of demographic situation, constant «food crisis», rising unemployment, impoverishment of broad layers of population, increased migration - create a favourable social base for radical extremist movements and terrorist forces and is the basis for destabilization of the situation in both individual regions and the whole world.

The security environment in the medium and long term is characterized by the number of challenges and threats to the national security of Ukraine that are related to possible use of military force against it: the infringement against state sovereignty and territorial integrity of Ukraine by foreign states, terrorist organizations and separatist movements operating in Ukraine; simplification by the Russian Federation of legal procedures on the use of military force beyond its own territory, justification of the use of military force as means of settling international disputes; interference into the internal affairs of Ukraine by the foreign states, including the support of political and other organizations, the activities of which are aimed at violation of the constitutional order, territorial integrity and sovereignty of Ukraine, internal socio-political stability, law and order; impediment to Ukraine's joining the existing and perspective collective security systems; violation by states of international agreements, agreements on non-proliferation of weapons of mass destruction and their means of delivery, arms control, limitation and reduction of armaments; building up of forces and materiel near the southern and eastern borders of Ukraine, establishment of new and expansion and modernization of existing military bases and facilities, causing the imbalance of powers in the region; aggravation of humanitarian problems related to the internal movement of population from the zone of armed conflict in the eastern Ukraine and the occupied Autonomous Republic of Crimea; activation of intelligence, reconnaissance and sabotage activities of the foreign special services, and 
other governmental or non-governmental international organizations against Ukraine; disclosure of information constituting a state secret, illegal collection and use of information in the areas of defence, state security, economy, science and technology, and endangering information security of the state; danger of committing terrorist acts, including in cyberspace, on critical infrastructure facilities of Ukraine by the reconnaissance and sabotage groups of special services of foreign states, terrorist organizations and separatist movements operating in Ukraine; promoting illegal import of weapons, ammunition, explosives, radioactive materials and narcotics, weapons of mass destruction to Ukraine; using the crisis in Ukraine-Russia relations by foreign countries to shake out Ukraine from the traditional arms markets, discredit Ukraine as a reliable partner in the issues of military-technical cooperation; using energy, trade and economic dependence of Ukraine to achieve politico-military objectives; using military force in the region or involving states in the region, presence of «frozen» conflicts, including those near the borders of Ukraine, and creating conditions to spread instability in Ukraine; enhancing separatist sentiments in areas densely populated by ethnic minorities in Ukraine, and active support of such activities by individual countries; political, financial, military or other support of paramilitary or armed groups, terrorist organizations in Ukraine that are not provided by law; strengthening information and psychological influence on Ukraine in order to destabilize politicosocial situation in Ukraine or in certain regions and areas densely populated by ethnic minorities; using of political or economic sanctions against Ukraine, the suspension of diplomatic relations with Ukraine; violation of the Convention on the High Seas of 1958 because of piracy acts against marine vessels or aircraft of Ukraine; increasing flow of irregular migrants to Ukraine or through its territory as a result of armed conflicts, deterioration of the socio-economic situation of individual countries. Internal environmental and technological challenges and threats will significantly affect the National Security of Ukraine in particular: excessive man-made impact on the territory of Ukraine, increasing the possibilities of man-made and natural disasters; obsolescence of equipment of high-risk sites, communal infrastructure of residential areas and waste treatment facilities of enterprises; environmental abuse, radioactive, chemical and biological pollution, a problem of transboundary pollution; ineffectiveness of measures taken to manage the negative consequences of the military and other environmentally hazardous activities; deterioration of the ecological state of water basins, aggravation of the transboundary pollution and water quality deterioration, aggravation of technogenic status of hydraulic 
engineering structures of the multireservoir system on the river Dnipro; inadequate control over import to Ukraine of environmentally unsound technologies and materials, pathogenic agents, use of genetically modified organisms ${ }^{11}$.

Capabilities of Ukraine to respond to these challenges and threats are limited by such internal conditions and factors: difficult economic situation, high level of population poverty and unemployment; corruption, high level of crime, including organized and armed; radicalisation of political parties and movements; the presence of cultural, religious and language contradictions in the society; unresolved issues related to the delimitation of Ukrainian borders; incompleteness of the reform of Unified State Civil Defence System; disequilibrium and incompleteness of system reforms, including those in the defence sphere of Ukraine; ineffective state policy on defence planning and military construction; low level of the defence capability of Ukraine, insufficient mastering of forms and methods of modern warfare by the Armed Forces of Ukraine and other military formations; vulnerability of information infrastructure of the state, first of all critical information infrastructure facilities; imperfection of training system, insufficient level of practical proficiency of military experts and their adaptation to the modern warfare conditions; low level of defence orders, actual absence of search and applied works related to the production of high-tech defence products; technological obsolescence of the equipment of military-industrial complex enterprises; lack of closed cycles of domestic production of a considerable materiel; outflow of highly skilled experts of the militaryindustrial complex from Ukraine; sharp decrees of the competitiveness level, and moral obsolescence of domestic defence and dualuse goods ${ }^{12}$.

The features according to which the activities of other states (coalitions of states) are classified as threat of use of military force against Ukraine and give grounds to identify potential military enemy, include: raising the ultimatum, satisfaction of which may result in violation of the constitutional order, territorial integrity and sovereignty of Ukraine; suspension of diplomatic relations with Ukraine; permission of another state to use its territory by a third state (coalition) for the preparation and commitment of aggression against Ukraine; the adoption of the regulatory act by another state, allowing the use of its armed forces on the territory of

\footnotetext{
${ }^{11}$ Про створення експертно-аналітичної групи Міністерства оборони України з питань проведення за- ходів оборонного огляду : Наказ Міністерства оборони України № 397 від 17 черв. 2014 р. 3 с.

12 Щипанський П. В. Нове безпекове середовище - прогнозовані виклики та загрози національній безпеці України. П. В. Щипанський, П. М. Крикун, О. В. Устименко. Зб. наук. пр. Центру воєнностратегічних досліджень Нац. ун-ту оборони України ім. Івана Черняховського. 2015. № 1 (53). C. $107-113$.
} 
Ukraine; economic and information blockade of Ukraine; acts of provocation on the state border of Ukraine; actions disrupting military formations and special-purpose agencies' $\mathrm{C} 2$ system, or resulting in the impossibility of execution of functions by the national security actors; activation of intelligence and subversive activities against Ukraine as well as military intelligence in Ukraine; political, financial, military or other support of armed groups or terrorist organizations in Ukraine that are not provided by law; conduct of general, limited mobilization or deployment of military forces, building up of groups of the armed forces of neighbouring countries, increasing the intensity of military exercises near the state border of Ukraine; leaving without the agreement with Ukraine provisions on the location of units of the armed forces of another country, which according to the concluded international agreements stay in Ukraine, as well as on the activities to use such units against a third country; actions disrupting the security of the nuclear and chemical industry facilities, military-industrial complex, facilities storing materiel, ammunition, and other potentially dangerous items ${ }^{13}$.

\section{Features of decentralization of local authorities in Ukraine}

The system of government in Ukraine is not fulfilling the role assigned to it, because there is twofold subordination and uncertainty powers of representative and executive bodies. Today there is a threelevel administrative division: basic level (village, town or city), district level and level area. There is a local government council and executive body (all the decisions and programs approved by the Regional Council performed by RSA, those public authorities). On the one hand, the council is formed in the general election; on the other hand there is executive body - the State Administration. Thus, there is a conflict between appointed and elected government.

The situation is similar at the district level, where all the heads of administration by the Constitution (Law of Ukraine, 1997) are appointed by the President. By 28 December 2014 baseline had the resources to fulfil their mandate (resources coming from the state budget through the area). Thus there is a need for continued reform of local government on the principles of decentralization and subsidiary principle (Reform concept, 2014), as they are the foundation for building the state. The basis of this principle is the understanding and acceptance of the fact that all problems should be solved at a basic level, the central government can

\footnotetext{
${ }^{13}$ 9. Нормативно-правова база у галузі безпеки і оборони України. Вид. 2-ге, допов. К. : Центр дослідження армії, конверсії та роззброєння, 2017. С. 419.
} 
play a subsidiary, the subsidiary, not a subordinated role, and should give the regions the opportunity to make decisions ${ }^{14}$.

As you know, the regions of our country developing unevenly: someone has minerals, others - developed industry, someone - agriculture and others. So the state should allow them to find their path of development and thus, at the community level, to decide how they want to develop further. Each unit of government is a legal entity, has property rights and powers delegated by the state. For which it shall have sufficient financial resources, and the state owes most of these resources to leave the field. Currently, the law provides (Law of Ukraine, 2006), which is based on state regional program area should adopt their own local programs. Each approved program will receive Regional Development Fund (totalling three billion UAH) funds, $80 \%$ of which will be distributed evenly, and $20 \%$, respectively, to those who can no longer finance its part.

Thus, the distribution mechanism Regional Development Fund becomes transparent and understandable. Previously the government determines to which region and on financing coming today law provides for the interdepartmental commission, which will be the body that coordinates the execution and implementation of programs. Locally created regional development agencies with OSA on the basis of publicprivate partnership (these belong to representatives of the chamber of commerce, NGOs, and local authorities). For example, in the EU (Hungary, Slovakia and Poland) to promote regional development created a separate executive agency. Now, for the regional development of our country, the EU has allocated 55 million euro, will implement a number of small programs. If these funds are used wisely, next year you can expect a much larger amount to half a billion USD.

Proposal reforms to decentralize power on the ground are that the three-tiered structure remains, but unlike the current situation where at district and area is under State Administration and State Administration, through amendments to the Constitution should be established district and regional executive bodies. For example, the state council approves the executive committee during the session, as the district council will form its executive committee. Exist and district administration and state administration, which appointed the President of the Government's submissions. This reform should take place through changes in the

\footnotetext{
${ }^{14}$ 10. Kropyvko M.F., \& Malik M.J. Integration and self-organization of the agricultural business in the decentralization of power: monograph. K.: NNC IAE, P. 224.
} 
Constitution. As a result, local authorities will lose their atypical features - such as enforcement of regional or district council ${ }^{15}$.

They were left alone control function and implementation of government programs, as head of the local administration appointed by the President on the proposal of the Government. Also, the administration will coordinate the activities of executive bodies in the regions (for example, pension funds, prosecutors, and police). Rather than carry out the decisions of local governments, the administration will carry out overall control and supervision of regional and district councils.

Thus, the powers of local state administrations can be divided into: own - exercise executive functions in certain areas (software protection, orphans, etc.); coordination - coordination of territorial bodies of central executive bodies within the area and the region; Control - for control of the legality of acts of local government and the quality of local government public services. And to the office of the district are: Maintenance of common property territorial community area; - Transport infrastructure of regional importance; - Education and training of children in boarding schools, youth sports school; - Provision of secondary health care (medical centres, hospitals, maternity homes, etc.) ${ }^{16}$.

Features of decentralization of public administration reform One of the hallmarks of a modern democratic society has become political decentralization, the function of which is the implementation of a public authority which is independent of the state entities unrelated relationship of subordination.

The degree of autonomy is determined that they belong to a relatively independent of the type of public authority - local government. Thus, decentralization of public power implies exclusion of a self-governing part of the government formation with fixing this exclusion as in the Constitution, so (mostly) and current legislation. The People's Deputies identify the legal and organizational basis of the right of territorial communities to participate in public control over the implementation of their rights. Public control will affect local governments and utilities. The corresponding proposal contains a draft law "On public control". The bill provides that public control - is the work of public control, such as full members of the territorial community, local departments of public associations and political parties, community organizations and MPs of supervision, inspection and evaluation of: - local governments; - public

\footnotetext{
${ }^{15}$ On ratification of the European Social Charter (revised): Law of Ukraine of 14.09.2006. Number 137-V. Retrieved from: http://zakon.rada.gov.ua

${ }^{16}$ On local government in Ukraine: the Law of Ukraine of 21.05.1997 p. Number 280/97-VR. Retrieved from: http://zakon.rada.gov.ua
} 
enterprises, institutions and organizations; - educational and health care, culture and social protection; - legal and physical persons - service providers in the relevant community.

Also, this project concerns legal and physical persons that receive the local budget, as well as those whose work affects the interests of the local communities in terms of environmental pollution, fire safety, sanitaryepidemiological and radiological situation of food safety. The activities of the mentioned bodies will be tested on the compliance of such activities with the laws of Ukraine and the interests of the local community. The procedure for the implementation of public control should take place in a sociological and statistical research, public monitoring, assessment and verification, reporting on the work of public control, preparation and submission of proposals to local authorities on the results of public control, discussing the subject of public scrutiny at public meetings. Reports subjects of public control of the work are available to the public without fail by their publication or public hearing. Thus, this law will increase the openness and transparency of local government, enterprises, institutions and organizations. Thus, the specificity of decentralization alienation of government necessitates the division of socially important needs and interests to those whose satisfaction is a function only of the state, and those, the implementation of which can be transferred to other entities. Only because of this clear separation of State may transfer to other entities of significant secondary for themselves but socially necessary functions ${ }^{17}$.

Dismissal States from these features contribute to the stabilization of the government as the practical implementation of a number of socially necessary functions close to the consumer of public services and state removed from responsibility for certain functions. However, incorrect distribution of functions without regard to their social significance, the exercise of those or other entities to ensure implementation of the necessary resources and responsibilities may adversely affect the ordering of public life. However, one should take into account aspects under which the centralization policy is seen as the only constructive consolidating and stabilizing society.

The need for reforms to strengthen the political status of local government The need to strengthen the political status of local government as a junior public authorities have in many scientific studies. But, clearly, this is backed up not only referring to the generally recognized principles of democracy and European standards, but more

\footnotetext{
${ }^{17}$ On cooperation of communities: Law of Ukraine of 06.17.2014 p. Number 1508-VII. Retrieved from: http://zakon.rada.gov.ua
} 
real facts that emphasize the effectiveness of management of decentralized power ${ }^{18}$.

The most convincing of these are:

The decentralized power provides a more efficient allocation of resources in the sector of public goods. This fact is based on the notion that these kinds of benefits depends on the needs and interests of people living in a particular area. As a result, the institutional system, in which political decisions taken at local and regional levels to make those resources, is making public option more accurate. As a result, rational policy supports particularly those development programs which promote the growth of the prestige and increase the chances of winning the next election. Thus public choice at the local level allows better meet the needs of the population in public goods and services without increasing the volume of resources.

Decentralization enhances the controllability of the public authorities of the local communities, as the link between taxes paid and the provision of public goods is more direct and transparent. Local politicians are more difficult to hide the inefficiency of public spending, forcing them to be more responsible in developing and implementing local policies.

Availability of own competence of local public authorities in forming the local tax base and the disposal of local budgets, availability of appropriate material and financial resources enables them to form an independent policy development of local communities, encourages them to reduce unjustified costs in the public sector. Thus, hover facts make it possible to assert that the reform of local self-government and territorial organization of power in Ukraine is impossible without political will, which would contribute to the adoption of a significant number of laws and the will of local communities to unite. After the process of decentralization and reform of administrative and territorial structure in many European countries lasted more than 5 years, so you cannot expect instant results by adopting the necessary laws.

Research methodology The methodological base for research on decentralization and local government reforms to strengthen the political status of local government and decentralization of public power is the Constitution of Ukraine, Laws of Ukraine, Decrees of the President of Ukraine, as well as publications on these issues of domestic and foreign authors. In this direction domestic scientists have taken a number of important steps, including the study of the theoretical foundations of

\footnotetext{
${ }^{18}$ Pron'ko L. (2016). Decentralization of power and the beginning of local government reform in Ukraine. Economy in the context of innovation development: state and prospects: materials of International scientificpractical conference (12-13 February). Uzhgorod, p. 163.
} 
government, constitutional principles of its implementation, the history of government in Ukraine, features contemporary national governments. Restructuring local government in Ukraine and Poland's experience in reforming local government investigated many Ukrainian scientists in 2013, 2014, 2015, respectively.

Findings Systematic reforms in terms of priority must be given a New Constitution that guarantees enhanced political status and European standards of local government. International experience and practice show that the reform process must start building the foundation of territorial authorities to build economically capable community to reform the administrative and territorial structure.

\section{CONCLUSIONS}

Implications of these and other challenges and threats may be the use of military force against Ukraine through armed aggression (according to the features listed in the Law of Ukraine «On the Defence of Ukraine»), armed conflict on the state border or within the country, involving Ukraine into military conflict between other states. These ways of military threat materializing may be combined with one another and arise consecutively or simultaneously. In view of the trends and conditions of the development of the security situation around Ukraine, the possibility of aggravation of the politico-military crisis and its escalation into a local or regional war in the short and medium term is considered to be serious.

Update the constitution makes sense only if the implementation of new constitutional provisions will open the prospect of the adoption of laws necessary for optimization of the public authorities, the territorial organization of power in Ukraine, improving local governance. The implementation of these tasks is the essence of true reforms in decentralization of power and development of local self-government. They should create institutional preconditions for the implementation of various sectoral reforms. According to many experts, the reform for Ukraine should take place in two phases: voluntary and systematic. At the current stage of voluntary adopted the Law "On voluntary association of communities", "On cooperation of local communities", "On Principles of regional policy." Systemic step is to amend the Constitution, the adoption of new laws "On Local Government", "On local state administrations" (that they were not executive bodies and supervised and coordinated state policy), "On service in local government" (to finally determine who is a civil servant in the city council). 


\section{SUMMARY}

Adopting the constitutional amendments would be the most favorable outcome for continued decentralization, as this would enable substantial devolution of authority at the sub-national level. Replacing the constitutional changes with piece-meal legislation would bring limited success in establishing oversight over sub-national governments, while at the same time risking to backfire through further centralization and potential abuse of power by national authorities. As with many reforms in Ukraine, passing the constitutional amendments would require sustained engagement and pressure from a variety of actors. Our recommendations below are addressed to the Ukrainian authorities, domestic civil society, and the international community.

\section{REFERENCES}

1. Ситник Г. П. Державне управління у сфері націо- нальної безпеки (концептуальні та організаційно-правові засади) : підручник. Г. П. Ситник. К. : НАДУ, 2017. 544 с.

2. Семенченко А. І. Методологія стратегічного планування у сфері державного управління забезпеченням національної безпеки України. А. І. Семенчен- ко. К. : НАДУ, 2015. 428 с.

3. Богданович В. Ю. Основи державного управління забезпеченням обороноздатності України: теорія i практика. В. Ю. Богданович, М. Ф. Єжеєв, І. Ю. Свида. Львів : ЛІСВ, 2015. $300 \mathrm{c}$.

4. Сектор безпеки і оборони України : зб. наук. матеріалів / [Ф. В. Саганюк, М. М. Лобко, О. В. Устименко, В. І. Пеньковський] ; за ред. Р. І. Тимошенка. К. : Майстер книг, 2018. 174 с.

5. Yarger Harry R. (Harry Richard) Strategy and the national security professional : strategic thinking and strategy formulation in the 21 th century. Harry R. Yarger.

6. National Security Strategy and Strategic Defence and Security Review 2015 [Електронний ресурс]. - Режим доступу : https://www.gov.uk/government/

uploads/system/uploads/attachment_data/ file/478933/52309_Cm_9161_NSS_SD_Review_web_only.pdf

7. Про створення експертно-аналітичної групи Міністерства оборони України з питань проведення за- ходів оборонного огляду : Наказ Міністерства оборони України № 397 від 17 черв. 2014 р. 3 с.

8. Щипанський П. В. Нове безпекове середовище - прогнозовані виклики та загрози національній безпеці України. П. В. Щипанський, П. М. Крикун, О. В. Устименко. Зб. наук. пр. Центру воєнно- 
стратегічних досліджень Нац. ун-ту оборони України ім. Івана Черняховського. 2015. № 1 (53). С. 107-113.

9. Нормативно-правова база у галузі безпеки і оборони України. Вид. 2-ге, допов. К. : Центр дослідження армії, конверсії та роззброєння, 2017. $800 \mathrm{c}$.

10. Kropyvko M.F., \& Malik M.J. Integration and self-organization of the agricultural business in the decentralization of power: monograph. K.: NNC IAE, $447 \mathrm{p}$.

11. On ratification of the European Social Charter (revised): Law of Ukraine of 14.09.2006. Number 137-V. Retrieved from: http://zakon.rada.gov.ua

12. On local government in Ukraine: the Law of Ukraine of 21.05.1997 p. Number 280/97-VR. Retrieved from: http://zakon.rada.gov.ua

13. On cooperation of communities: Law of Ukraine of 06.17.2014 p. Number 1508-VII. Retrieved from: http://zakon.rada.gov.ua

14. Pron'ko L. (2016). Decentralization of power and the beginning of local government reform in Ukraine. Economy in the context of innovation development: state and prospects: materials of International scientific-practical conference (12-13 February). Uzhgorod, p. 163-166.

\section{Information about the author:} Bortnyak V. A.

Candidate of Law Sciences, Assistant Professor, Assistant Professor at the Department of Constitutional and International Law of the Educational and Humanitarian Institute of the V. I. Vernadsky Taurida National University

33, Ivan Kudria str., Kyiv, Ukraine 